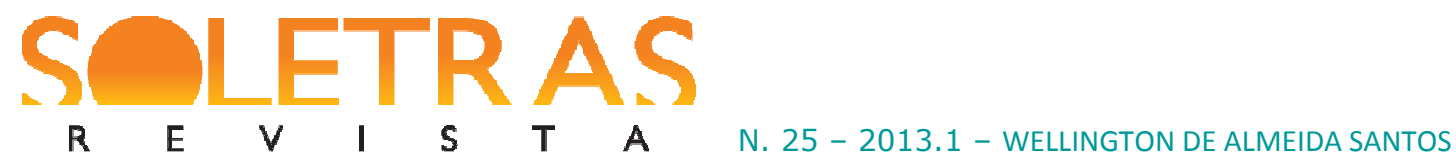

\title{
Manuel Bandeira e o diálogo com a tradição poética
}

\author{
Wellington de Almeida Santos ${ }^{1}$
}

Resumo: A tematização da morte abre e fecha com destaque a longa trajetória poética de Manuel Bandeira. O objetivo deste trabalho é demonstrar que o poeta superou o sentimento trágico da morte pelo diálogo com outros poetas e até com a própria obra, entre outras formulações possíveis, através de uma singular dialética poética. Para comprovar a viabilidade e relevância desse caminho crítico, utilizou-se um instrumental teórico com base na técnica intertextual e procedimentos críticos assemelhados.

Palavras-chave: Manuel Bandeira. Intertextualidade. Poesia.

Manuel Bandeira sempre se declarou um lírico contumaz, atribuindo à inspiração papel relevante na gênese de boa parte de seus poemas, inclusive alguns dos mais representativos. Ao estabelecer tal vínculo, inscreveu-se definitivamente na tradição clássica, atualizada com mais rigor pela estética romântica.

Desde a Grécia antiga, houve uma complexa e diversificada teoria que responsabilizava as Musas, divindades tutelares, filhas da memória (Mnemósine) pela atividade intelectual, sobretudo pelos trabalhos científicos e artísticos. Não é oportuno desenvolver considerações detalhadas sobre a tipologia, a função e as transformações das Musas na literatura ocidental. É interessante assinalar, no entanto, a aproximação possível entre a concepção bandeiriana de inspiração e a clássica formulação, sobretudo de origem platônica, que considera o poeta um "possuído", um ser destituído de razão, conforme se pode depreender de uma célebre passagem do Íon, em que Sócrates define o poeta como aquele que "é uma luz e uma coisa alada e sagrada, jamais capaz de compor enquanto não se sentir inspirado, e estiver além de si mesmo, quando a razão já não está com ele” (PLATÃO, apud READ, 1967, p. 124).

No dizer autorizado de Herbert Read, "é esse, portanto, o conceito clássico da Musa: uma divindade que ocasionalmente priva um ser humano de seus sentidos e o utiliza como porta-voz involuntário de uma manifestação divina" (READ, 1967, p. 124).

$\mathrm{Na}$ modernidade, foram os poetas românticos os que melhor atualizaram a crença no poder da inspiração como principal ou única fonte de criação poética, agora calcada na força

\footnotetext{
${ }^{1}$ Wellington de Almeida Santos é professor aposentado da Faculdade de Letras da Universidade Federal do Rio de Janeiro (UFRJ), na classe de Associado II. Doutorou-se em 1987, pela Faculdade de Letras da UFRJ, com a tese Poética e poesia de Manuel Bandeira. Publicou recentemente Teófilo Dias: antologia e estudo crítico (Rio de Janeiro: Academia Brasileira de Letras, 2012). Atualmente, reside em Conservatória, RJ. E-mail: wdealmeidasantos@yahoo.com.br.
} 
do inconsciente. Depois dos românticos, a crença nesse tipo de inspiração entrou em declínio e foi até posta em ridículo pelos movimentos literários posteriores, notadamente o Parnasianismo, embora ainda persista o nome de inspiração para nortear o impulso criador, numa acepção diferente daquela formulada pelos românticos. A inspiração, tal como formulada pelos românticos, também foi abandonada pelos movimentos de vanguarda do século XX, exceto o Surrealismo que, André Breton à frente, creditava ao subconsciente a realização da fatura artística. É bastante conhecida nos meios intelectuais a anedota, cuja autoria se atribui a André Breton, de que colocava uma tabuleta na porta de seu quarto, quando ia dormir, com a seguinte inscrição: "Poeta trabalhando".

Manuel Bandeira devolveu a discussão à ambiência romântica, em cuja tradição se filia, declarando-se um poeta inspirado: "não faço poesia quando quero e sim quando ela, poesia, quer" (BANDEIRA, 1954, p. 115). A importância desse depoimento diante do mistério da criação poética torna-se o emblema de um paradoxo, quando se estabelece o confronto entre o poeta inspirado e a personalidade do poeta consciente. De um lado, há o Manuel Bandeira insistindo na tese do poeta inspirado, largamente reafirmada em entrevistas, cartas, crônicas e outros documentos de teor biográfico, como nessa passagem do Itinerário de Pasárgada, essa fonte preciosa de informações sobre sua formação e desenvolvimento literário:

Na minha experiência pessoal fui verificando que o meu esforço consciente só resultava em insatisfação, ao passo que o que me saía do subconsciente, numa espécie de transe ou alumbramento poético, tinha ao menos a virtude de me deixar aliviado de minhas angústias. Longe de me sentir humilhado, rejubilava como se de repente me tivessem posto em estado de graça (BANDEIRA, 1954, p. 24).

De outro lado, existe o Manuel Bandeira extremamente zeloso da técnica versificatória, o estudioso sagaz, sensível e penetrante da poesia alheia. Suas anotações sobre edições críticas de poetas brasileiros (Gonçalves Dias), preparo de várias antologias poéticas (do Romantismo e do Parnasianismo, por exemplo), tradução de poetas estrangeiros de diferentes línguas, ensaios e diversos artigos, além da correspondência com amigos, sobretudo Mário de Andrade, denunciam um estudioso extraordinário de assuntos ligados à poesia, talvez o mais habilidoso artista do verso de toda a história da poesia brasileira, parece desmentir o poeta "alumbrado":

Mas ao mesmo tempo compreendi, ainda antes de conhecer a lição de Mallarmé, que em literatura a poesia está nas palavras, se faz com palavras SOLETRAS - Revista do Departamento de Letras da FFP/UERJ 
e não com ideias ou sentimentos, muito embora, bem entendido, seja pela força do sentimento ou pela tensão do espírito que acodem ao poeta as combinações de palavras onde há carga de poesia (BANDEIRA, 1954, p. 24).

Entre o primeiro e o segundo fragmentos transcritos parece haver um obstáculo de difícil transposição. No primeiro, as expressões "subconsciente", "transe", "alumbramento" e "estado de graça" remetem a uma concepção transracional da criação poética, de que o poeta se declara devedor e dependente. No segundo, as expressões "em literatura a poesia está nas palavras", "se faz com palavras" ou "combinações de palavras" atestam o controle racional na organização formal do poema ou, pelo menos, a vontade consciente e lúcida de fazer poesia.

Octavio Paz, em exemplar exposição, também admite a existência desses dois tipos de poetas, mas não em estado puro:

No caso do poeta reflexivo tropeçamos numa misteriosa colaboração alheia, com a aparição não invocava de outra voz. No caso do romântico deparamo-nos com a não menos explicável presença de uma vontade que faz do murmúrio um todo arranjado e dono de uma obscura premeditação (PAZ, 1982, p. 193-194).

E arremata, categórico, optando pela proposição de que há um só tipo de poeta, o inspirado e, ao mesmo tempo, perfeitamente consciente de seu trabalho: "O ato de escrever poemas se oferece a nossos olhos como um nó de forças contrárias, no qual nossa voz e a outra voz se enlaçam e se confundem" (PAZ, 1982, p. 194).

Manuel Bandeira reitera sua condição de poeta inspirado, admitindo sua filiação ao temperamento romântico, afinidade que o aproxima de Shelley, para quem "a poesia não é, como o raciocínio, uma força para ser exercida conforme a determinação da vontade" (SHELLEY, 1972, p. 88). As declarações sobre a gênese de certos poemas asseguram que nele intervieram forças alheias ao domínio consciente, sobretudo o sonho, o delírio febril e os constantes estados de puro devaneio, convicto de que a veia romântica estava inelutavelmente ligada à sua personalidade poética:

Desejo dizer alguma coisa a respeito dos poemas que tenho feito durante o sono. Foram numerosos. Infelizmente não os pude recompor depois de acordado. Só duas vezes o consegui. Da primeira vez imperfeitamente foi o caso de "Palinódia" [...]. 
Do "Lutador" eu me lembrava quase integralmente, havia um ou outro claro, que precisei encher depois de despertado (BANDEIRA, 1954, p. 123).

A força do inconsciente fora tão abrangente que se considerou um estranho diante da própria criação, dizendo um pouco adiante: "tanto esse soneto ("O lutador") como a "Palinódia" são coisas que tenho de interpretar como se fossem obras alheias" (BANDEIRA, 1954, p. 125). E, quando comunicou a Mário de Andrade que o soneto "Renúncia" (A cinza das horas) "foi feito com $40^{\circ}$, vômitos, suores frios, escarro de sangue" (BANDEIRA, 2000, p. 166), recebeu de volta um comentário desabonador, a que reagiu indignado: "believe it or not, o meu soneto 'O lutador' foi feito, fez-se em mim durante o sono" (BANDEIRA, 1958, p. 47-48), escreveu, em nota apensa à correspondência, na oportunidade em que publicou-lhe as cartas em livro.

Bandeira ficou tão transtornado com o descrédito e zombaria de Mário que até trocou o título do soneto (“O lutador" só seria publicado mais de vinte anos depois do malogrado episódio).

Um dos exemplos mais extraordinários desse processo de criação "espontânea" aconteceu em estado de vigília, num momento de singular emoção, desencadeado por uma alta voltagem poética, um instante de puro devaneio, quando brotou a "Última canção do beco":

Na véspera de me mudar da Rua Morais e Vale, às seis e tanto da tarde, tinha eu acabado de arrumar os meus troços e caíra exausto na cama. Exausto da arrumação e um pouco também da emoção de deixar aquele ambiente onde vivera nove anos. De repente a emoção se ritmou em redondilhas, escrevi a primeira estrofe, mas era hora de vestir-me para sair, vesti-me com os versos surdindo na cabeça, desci à rua, no beco das Carmelitas me lembrei de Raul de Leoni, e os versos vindo sempre, e eu com medo de esquecê-los, tomei um bonde, saquei do bolso um pedaço de papel e um lápis, fui tomando as minhas notas numa estenografia improvisada, senão quando lá se quebrou a ponta do lápis, os versos não paravam. De volta a casa, bati os versos na máquina e fiquei espantadíssimo ao verificar que o poema se compusera à minha revelia, em sete estrofes de sete versos de sete sílabas (BANDEIRA, 1954, p. 115-116). (Grifos meus).

Já mencionara as circunstâncias curiosas do aparecimento da gênese do poema, que se chamava então "Último poema do beco", em carta ao amigo Alphonsus de Guimarães Filho: "Tive muito prazer fazendo esses versos, pois havia mais de um ano que a inspiração não vinha" E concluiu, aludindo ao fato de o poema constar de sete estrofes, de sete versos, de 
sete sílabas: "hão de pensar que foi de caso pensado. Pois não houve a menor intenção" (BANDEIRA, 1974, p. 82-83). (Grifos meus).

Houve até casos extremos de desconhecimento momentâneo de autoria, tão desligado estava o poema da memória consciente do poeta: "Os meus versos "Consoada" foram encontrados numa pasta e em estado informe; tinha-me esquecido e a princípio num pude compreender do que se tratava, pensei até que fosse algum ensaio de tradução; depois me fui lembrando que era resíduo da tentativa fracassada de poema" (BANDEIRA, 1954, p. 122).

Em outras ocasiões, o processo de gestação ficou hibernando até explodir em expressão verbal explícita. É o caso de "Vou-me embora pra Pasárgada" (Libertinagem) que, segundo ele, foi o poema de mais longa espera em toda a sua obra. A realização integral só foi possível muitos anos depois (mais de vinte), após ter pressentido o esboço inicial. Na época propícia, a emoção se materializou em palavras:

Quando eu morava só na minha casa da Rua do Curvelo, num momento de fundo desânimo, da mais aguda sensação de tudo o que eu não tinha feito na minha vida por motivo da doença, saltou-me de súbito do subconsciente esse grito estapafúrdio: "Vou-me embora pra Pasárgada!" Senti na redondilha a primeira célula de um poema, e tentei realizá-lo, mas fracassei. Já nesse tempo eu não forçava a mão. Abandonei a idéia. Alguns depois, em idênticas circunstâncias de desalento e tédio, me ocorreu o mesmo desabafo de evasão da "vida besta". Desta vez o poema saiu sem esforço como se já estivesse pronto dentro de mim (BANDEIRA, 1954, p. 93).

Não obstante essa infinidade de depoimentos, Manuel Bandeira se inscreve na concepção formulada por Octavio Paz, a de que o poeta inspirado é simultaneamente reflexivo. Isso pode ser comprovado pelo cotejo entre o esboço que é produto da inspiração (poema transcrito tal como se apresentou no momento da inspiração, inclusive a "Última canção do beco") e o produto final, na época de sua divulgação em livro.

Apesar desse substrato, cuja importância é apenas relativa e, em muitas oportunidades, tem valor meramente anedótico ou, no mínimo, curioso, quer-se ressaltar a faceta lúcida e criativa de Manuel Bandeira, a qual revela um poeta bastante complexo, sob aparente facilidade, mercê de sua altíssima capacidade de, com o mínimo de recursos de linguagem, extrair o máximo das potencialidades expressionais da palavra. O longo convívio com poetas de todas as épocas e de diferentes línguas, além do exercício regular da literatura, inclusive como profissional (foi professor do Colégio Pedro II, do Rio de Janeiro, e da antiga Faculdade Nacional de Filosofia, atual Faculdade de Letras da UFRJ, onde lecionou literatura hispano- 


\section{$\begin{array}{llllllll}\mathbf{R} & \mathbf{E} & \mathbf{V} & \mathbf{I} & \mathbf{S} & \mathbf{T} & \mathbf{A} & \text { N. } 25-2013.1 \text { - WELLINGTON DE ALMEIDA SANTOS }\end{array}$}

americana) e como autor de livros (antologias poéticas, edições críticas, tradução de várias línguas) fez dele um poeta compulsoriamente enciclopédico, inclusive com a bagagem de sua própria obra. Conhecer essa presença alheia e própria na sua obra poética é mergulhar um pouco mais fundo no seu fascinante universo poético.

Em 1966, ao preparar a edição definitiva de suas poesias completas, a que deu o título geral de Estrela da vida inteira (por sugestão de Otto Maria Carpeaux), reunindo todos os seus livros de poesias, desde o inaugural A cinza das horas (1917) até o último, Estrela da tarde (1958, segunda edição aumentada em 1963), incluiu nela um poema inédito, datado de 1965, intitulado "Antologia".

A respeito desse poema, consta que confidenciou, em carta, ao amigo Odylo Costa, Filho, sua intenção, conforme registro de Gilberto Mendonça Teles, sem informação de fonte bibliográfica: "Tive a ideia de construir um poema só com versos ou pedaços de versos meus mais conhecidos ou mais marcados da minha sensibilidade, e que ao mesmo tempo pudesse funcionar como poema para uma pessoa que nada conhecesse da minha poesia" (BANDEIRA, 1980, p. 308).

Assim procedendo, Manuel Bandeira revitalizava explicitamente um tradicional recurso de construção poética da literatura latina, o centão. Esse termo veio do grego e foi incorporado ao vocabulário latino com diferentes acepções, entre as quais, primitivamente, "indicava uma espécie de manta de retalhos variados em tamanho, qualidade e cor, cosidos uns aos outros, com que se agasalhavam camponeses pobres (FONDA, p. 124). Esse sentido evoluiu e, incorporado à língua latina na categoria de termo literário, serviu para designar "uma composição poética formada de diferentes versos ou hemistíquios e dispostos de tal modo que formem, em sua nova unidade, um sentido diferente do que apresentam no texto primitivo" (FONDA, p. 125).

"Antologia" é um autêntico centão, rigorosamente construído segundo o modelo latino: "uma colcha de retalhos" poética, tecida com "retalhos" de onze poemas.

Antes de examiná-lo, a pretexto de introdução, verifique-se de que maneira o procedimento ganhou amplitude na obra bandeiriana, em menores proporções, assim como o conceito de centão coincide, na moderna teoria crítica, com o conceito de intertextualidade. $\mathrm{O}$ termo "centão", enquanto categoria literária, é semelhante ao uso que se faz na linguagem crítica moderna de termos como "colagem", "montagem”, “citação", "apropriação de textos", processos que podem ser resumidos na atividade conhecida pelo nome de intertextualidade. 
É possível aproveitar o temo centão não só em sua formulação ortodoxa, mas, mediante ligeira adaptação semântica, sugerir seu uso para designar também o aproveitamento apenas parcial de um ou mais fragmentos para a construção de um novo texto. Essa nova formulação pode ser entendida, conforme pensamento de Roland Barthes, nos seguintes termos:

O texto redistribui a língua. Uma das vias desta desconstrução é permutar textos, farrapos de textos que existiram ou existem em volta do texto considerado e finalmente dentro dele; todo o texto é um intertexto; outros textos estão presentes nele, em diversos níveis, sob formas mais ou menos reconhecíveis (Apud VIGNER, 1988, p. 32).

Sem a necessidade que se impõe ao crítico literário de obedecer a certos protocolos de leitura, o escritor "passeia pelos territórios da literatura com uma desenvoltura que não é permitida ao crítico: nada declara, pode dialogar com outros escritores sem os chamar pelo nome, utilizar os bens alheios como se fossem seus" (PERRONE-MOISÉS, 1979, p. 211). Essa liberdade e amplitude em operar textos ou "farrapos" de textos impõem ao leitor uma limitação de conhecimento que corresponde ao que João Alexandre Barbosa chamou de "leitura do intervalo", "quando entre o que a obra diz e o modo pelo qual se diz, o leitor sente um descompasso, uma intenção não realizada, um discurso subjacente não integrado e que necessita de esclarecimentos adicionais para que possa ser absorvido por ele" (BARBOSA, 1990, p. 15).

Convém considerar a intertextualidade sob duas maneiras distintas, mas complementares: uma explícita, sempre que a leitura de um texto induza ao diálogo crítico com outro texto concreto, através de fontes documentais; outra implícita, toda vez que se filia uma obra a uma determinada categoria ou forma genérica (romance, tragédia, poesia lírica, soneto, elegia), seja por obediência a um padrão ou modelo, seja por rebeldia à tradição.

A poesia de Manuel Bandeira se inscreve em ambas as formas de intertextualidade, sob as mais variadas modalidades de vínculo.

A presença da morte e o retorno ao passado infantil são temas privilegiados na poética bandeiriana. Para o desenvolvimento desses temas, recorreu a artifícios estético-literários capazes de conferir consistência artística à atmosfera lírica por eles requerida. Encontrou na elegia e no topos do ubi sunt?, entre outros artifícios literários, os elementos ideais para alcançar seu objetivo, ultrapassando as limitações ocasionais do mero diletantismo. Cedo descobriu, a propósito de $A$ cinza das horas, que os versos contidos no livro não transcendiam 
sua experiência pessoal e que o desabafo sentimental, nesse caso, "pode ser comovente no plano humano, mas não no plano artístico" (BANDEIRA, 1954, p. 51).

Assim procedendo, corroborava o hoje clássico princípio eliotiano, de que "quanto mais perfeito o artista, mais completamente estão separados nele o homem que sofre e o espírito que cria" (ELIOT, 1962, p.29). Estribado na lição de Mallarmé, convenceu-se de que “em literatura a poesia está nas palavras, se faz com palavras e não com ideias e sentimentos, muito embora, bem entendido, seja pela força do sentimento ou pela tensão do espírito que acodem ao poeta as combinações de palavras onde há carga de poesia” (BANDEIRA, 1954, p. 24).

Aprofundou-se na reflexão constante desse princípio mallarmeano, fundamental para a concepção do discurso literário em sentido restrito. Entre outras providências, concebeu a revitalização de formas poéticas tradicionais, adaptadas à veiculação de temas específicos. $\mathrm{Na}$ tematização da morte, encontrou na elegia e discursos congêneres a forma preferencial de expressão.

O termo grego elegeia (elegia), de obscura etimologia, segundo Massaud Moisés, passou por uma conturbada trajetória semântica, chegando aos tempos atuais com o significado de "composição poética de tema triste, notadamente funéreo" (MOISÉS, 1974, p. 167). Por extensão, erigem-se em elegíacos os sentimentos de perda de qualquer bem, material ou espiritual, sobretudo o que envolve valor afetivo. A ausência irremediável de coisas ou pessoas queridas reveste-se de tons lamentosos, próprios da elegia. E que perda maior para o ser humano que a dos entes amados (parentes, amigos, amores fracassados ou interrompidos pela morte) ou de si mesmo, com seus fracassos existências? Fundamental na poética bandeiriana, o tema da morte encontra na elegia uma de suas mais vigorosas formas de representação. Esse tema costuma despertar reflexões de natureza filosófica sobre a existência humana e a tragicidade inerente à sua condição, traduzidas na efetiva consciência de que na vida tudo é vão, fugaz e perecível. A venerável chapa retórica do ubi sunt? (“onde estão?”) herdada da tradição latina encontrou no ambiente medieval, mediante determinadas constantes contextuais, condições excepcionais de permanência e divulgação, cujo auge se dá com a poesia de François de Villon, cristalizada na modelar "Ballade des dames du temps jadis”, com seu trágico refrão (“Mais où sont les neiges d'antan?”), conforme o monumental estudo de Johan Huizinga em O outono da Idade Média (HUIZINGA, 2010, p. 221-245). E chegou à modernidade, naturalmente com as mutações impostas pelo tempo. O ubi sunt? condensa uma pergunta sem resposta para falar de feitos ou pessoas notáveis que não mais 
existem, para ilustrar a vanidade de tudo que acaba com a morte, fim de todas as ilusões. Augusto Meyer utilizou o ubi sunt? como suporte teórico para analisar o poema "Profundamente" (Libertinagem). Para o eminente crítico, o tema da evanescência das coisas e das pessoas, implícito no motivo do ubi sunt?, encontrou no poema de Manuel Bandeira uma versão moderna e mais trágica, porque o clichê tem resposta, ao contrário do que preconiza a tradição. Numa espécie de homenagem poética, comovidamente agradecido pela belíssima interpretação que o grande ensaísta gaúcho fez de seu poema, Manuel Bandeira dedicou a ele o poema "Antônia" (Estrela da tarde), incluindo a dedicatória no corpo do texto:

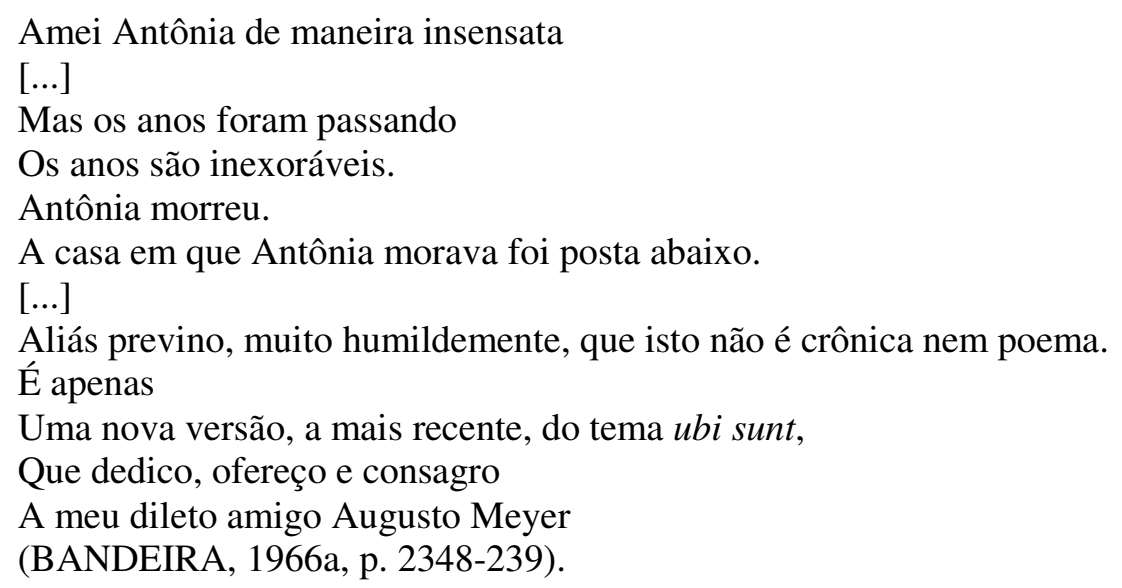

No poema seguinte, "Passeio a São Paulo", volta o ubi sunt?, desta vez para lembrar o grande amigo ausente, talvez o maior de todos, Mário de Andrade. Em meio à citação de versos do poeta paulistano, avulta o topos:

Onde as Juvenilidades auriverdes? Onde

A passiflora? o espanto ? a loucura? o desejo ?

Ubi sunt?

Ubi sunt?

- Obrigado, Mário pela tua companhia

(BANDEIRA, 1966a, p. 239).

A consciência de que tudo passa faz emergir do fundo da memória o outro extremo do viver, a infância plena. E o poeta lamenta que a tenha perdido, para sempre. Só o espaço poético é capaz de recuperá-la, através da elegia, sob o signo temático do ubi sunt?, costurada preferencialmente na forma de centão parcial, como na "Elegia de verão" (Opus 10): 
$\begin{array}{lll}\mathrm{S} & \mathrm{A}\end{array}$

O sol é grande. Ó coisas

Todas vãs, todas mudaves !

(Como esse "mudaves",

Que hoje é "mudáveis"

E já não rima com "aves")

$[\ldots]$

O sol é grande. Mas, ó cigarras que zinis

Não sois as mesmas que eu ouvi menino.

Sois outras, não me interessais...

Dêem-me as cigarras que eu ouvi menino.

(BANDEIRA, 1966a, p. 211).

"Elegia de verão" apropriou-se de dois versos de um belíssimo soneto de Sá de Miranda, o primeiro - "O sol é grande, caem co'a calma as aves" - e o quinto - "Ó cousas, todas vãs, todas mudaves" (MIRANDA, 1937, v. 1, p. 318).

A perda da infância impregna "Elegia de verão" de uma nostálgica lembrança do passado. A ação do tempo não perdoou sequer as formas vocabulares, as quais, como todas as coisas sensíveis, sofreram impiedosa corrosão temporal:

O sol é grande. Ó coisas

Todas vãs, todas mudaves!

(Como esse "mudaves",

Que hoje é "mudáveis"

E já não rima com "aves".)

(BANDEIRA, 1966a, p. 211).

Nos versos entre parênteses, pede desculpas por não manter a rima do "original" (sem que o leitor comum ou ignorante da alusão tenha consciência disso), insinuando, portanto, que a deformação ortográfica atual prejudicou a rima. Afirmação duplamente irônica, porquanto, primeiramente, a palavra "aves" não aparece em seu poema, e sim no soneto de Sá de Miranda, onde rima perfeitamente com "mudaves".

Conforme Umberto Eco, a literatura é dotada de um discurso dual (um alto e outro baixo) que marca um descompasso de leitura entre os diferentes receptores de uma determinada obra. Se uma obra contém referências cultas ou eruditas cujo significado está fora do alcance do leitor comum, isto não o impedirá da fruição, embora em nível menor que um outro leitor, dotado do aparato crítico suficiente para a apreciação dos elementos 
sofisticados por ventura nela existentes. A esse caráter ambíguo da literatura, Umberto Eco chamou de double coding (ECO, 2003, p. 199-218). Ainda segundo Umberto Eco, no segundo tipo de leitura pode surgir a "ironia intertextual, quando a obra faz citações ou apropria-se de outras para com elas estabelecer relações dialógicas, cujo significado só pode ser resgatado com o conhecimento das fontes. É o caso dessa referência à rima entre "aves" e "mudáveis", cuja compreensão integral só é percebida pela "ironia intertextual", isto é, pela leitura do soneto de Sá de Miranda.

Em segundo, lugar porque Manuel Bandeira bem sabia que o tipo de rima entre "aves" e "mudáveis é legítima em língua portuguesa (o conceito de rima está ligado à sonoridade e não à grafia da palavra). Logo ele que rimou de modo extravagante, não por puro virtuosismo, mas por necessidade funcional do verso, em "Vulgívaga" (Carnaval): "Não posso crer que se conceba / Do amor senão o gozo físico! / O meu amante morreu bêbado, / E meu marido morreu tísico!" (BANDEIRA, 1966a, p. 55). O transbordamento sintático do primeiro para o segundo verso e sua sugestão rítmica de queda prepara a rima com o terceiro verso, integrando som e sentido. E em "Elegia de verão" abandonou-se na identidade emocional com o poeta português, à saudade dos tempos de antanho. Sá de Miranda constata, entre angustiado e resignado, que tudo muda com o passar inexorável do tempo ("Eu vira já aqui sombras, vira flores / vi tantas águas, vi tanta verdura / [...] / Tudo é seco e mudo; e, de mestura, / também mudando-m'eu fiz doutras cores: / e tudo o mais renova, isto é sem cura!”). Manuel Bandeira reconhece que a recuperação da meninice, perdida no tempo passado, é impossível porque, tal como Sá de Miranda, o tempo provocou mudanças não só na natureza, mas também no "eu-lírico" que a recorda. E o ubi sunt? invade o poema, sem se mostrar concretamente. Implícita no verso “Deem-me as cigarras que eu ouvi menino”, está a pergunta desesperada (“onde estão as cigarras de minha meninice?”).

Na intertextualidade explícita, Manuel Bandeira não discriminou, nem hierarquizou, os textos de que se serviu. O inventário dessas referências textuais (exclui-se o Mafuá do malungo, por seu carácter circunstancial) é condição fundamental para se penetrar nos bastidores da criação bandeiriana e identificar neles as marcas ostensivas de um consciente trabalho de elaboração literária que recusa discretamente o rótulo de poeta inspirado, pelo menos em parte, com visíveis e vantajosos resultados em sua poética.

Certa vez, definiu o poeta como aquele que é capaz de "desentranhar" a poesia escondida nos textos não literários ou até em comunicações orais ("uma notícia de jornal, uma frase ouvida num bonde ou lida numa receita de doce ou numa fórmula de toilette"). E 
concluiu, com entusiasmo: "Eu, por mim, vivo cada vez mais atento a essa poesia disfarçada e errante. E um dos exercícios que mais me encantam é desentranhar um poema que está não raro desmembrado, desmanchado numa página de prosa” (BANDEIRA, 1958, v. 2, p. 284).

Confirmando o dito, há vários poemas "desentranhados": "Poema tirado de uma notícia de jornal" (Libertinagem), de procedência ignorada; "Poema desentranhado de uma prosa de Augusto Frederico Schmidt" (Lira dos cinquent'anos), adaptado de uma página encomiástica, publicada no livro Homenagem a Manuel Bandeira (1936), comemorativa dos cinquenta anos do poeta; "O homem e a morte" - romance desentranhado de "Um retrato da morte", de Fidelino de Figueiredo (Belo belo), reorganização em versos da segunda parte ("De frente") de uma narrativa em prosa do crítico português sobre a figura lendária de D. Juan, inserida no livro Um colecionador de angústias; "Uma face na escuridão - poema desentranhado de uma página de prosa de Dinah Silveira de Queiroz (Opus 10), cuja origem não foi localizada, e o "Poema encontrado por Thiago de Melo no Itinerário de Pasárgada" (Opus 10), o qual, de acordo com o título, foi construído a partir de um livro de Manuel Bandeira pelo próprio poeta, embora o "achado" seja atribuído a outro poeta (Thiago de Mello).

Sobre a gênese da admirável "Balada das três mulheres do sabonete Araxá" (Estrela da manhã), seu depoimento constitui-se na pista inicial para o resgate das fontes e consequente estabelecimento do diálogo intertextual pleno: “o trabalho de composição está em eu ter adequado às circunstâncias de minha vida fragmentos de poetas queridos e decorados em minha adolescência - Bilac, Castro Alves, Luís Delfino, Eugênio de Castro, Oscar Wilde" (BANDEIRA, 1954, p. 96-97).

Observe-se a destreza com que, em "Lua nova" (Opus 10), intrometem-se fragmentos de versos de outro poeta, sem indicação expressa de autoria alheia, criando a "ironia intertextual": "Não pensem que estou aguardando a lua cheia / - Esse sol da demência / Vaga e noctâmbula" (BANDEIRA, 1966a, p. 222).

No segundo e terceiro versos dessa estrofe (última do poema) aproveitam-se expressões retiradas do conhecido "Plenilúnio", de Raimundo Correia:

Astro dos loucos, sol da demência,

Vaga, noctâmbula aparição!

Quantos, bebendo-te a refulgência,

Quantos por isso, sol da demência,

Astro dos loucos, loucos estão!

(CORREIA, 1961, p. 347). 


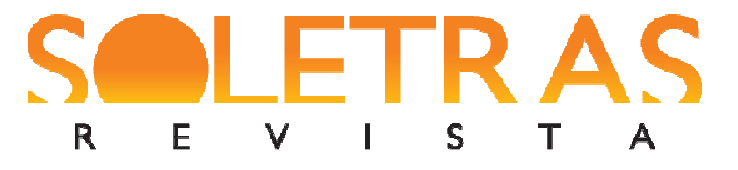

No poema de Raimundo Correia, a lua, referida por metáforas ("astro dos loucos", "sol da demência"), é signo de ambiência simbolista, de cunho pessimista.

Além da novidade da incorporação dessa espécie de "epígrafe", Bandeira desautomatizou a tradicional imagem da lua como símbolo de maus presságios, contrastando "lua cheia" (plenilúnio, "sol da demência") versus "lua nova". Atualizou a mítica imagem poética pela negatividade intertextual: "O que eu mais quero, / O de que preciso / É de lua nova" (BANDEIRA, 1966a, p. 222). Acrescente-se que se apropriou também de um fragmento de sua própria autoria. Trata-se dos versos "Meu novo quarto / Virado para o nascente / Meu quarto, de novo a cavaleiro da entrada da barra", os quais remetem ao verso de abertura do "Comentário musical" (Libertinagem): "O meu quarto de dormir a cavaleiro da entrada da barra" (BANDEIRA, 1966a, p. 107). A expectativa de um recomeço existencial, potencializada pela recusa do pessimismo lunar de Raimundo Correia, acentua a necessidade de uma renovação vital que se revela pela reiteração do signo "novo/nova", presente em "lua nova", "novo quarto" e "meu quarto, de novo", cuja semântica assume diversidade de significados. Esse hábil jogo de variações semântico-sintáticas encontra nos versos finais a imagem sintetizadora de seu estado de espírito ("O que eu mais quero, / O de que preciso / É de lua nova"), em face do irremediável aviso do verso mediano ("Todas as manhãs o aeroporto em frente me dá lições de partir:”).

Em "Cotovia" (Opus 10), a exemplo de "Elegia de verão", a incompatibilidade com o tempo presente do adulto é pretexto para o voo da memória retrospectiva, em busca da infância ingênua e feliz. O poeta recorreu, para garantir o clima de recusa do presente e consequente mergulho no passado aos antológicos versos de "Meus oito anos", de Casimiro de Abreu: “- Aurora da minha vida, / Que os anos não trazem mais!” (BANDEIRA, 1966a, p. 210).

Estrategicamente colocada no início do verso, com a inevitável inicial maiúscula, a palavra "Aurora" torna-se funcional e expressivamente ambígua: tanto faz referência ao significado temporal do poema de Casimiro de Abreu (aurora igual infância), como alude ao significado espacial do nome próprio Aurora (rua do Recife, onde o poeta passou a infância, imortalizada, junto com a rua da União, no famoso poema "Evocação do Recife") ou, ainda, nome de mulher. E, sem qualquer esforço mental ou interpretativo, agrega-se ao conteúdo semântico daquela aurora, tão admirada e apropriada dos versos de Castro Alves que, no seu caso, remete ao nascer do dia e, por simetria, à metáfora da infância. 
E não faltam, no mesmo poema, referências ao Camões de Os lusíadas, nos versos "Põe-me em perpétuo e mísero desterro / Na Cítia fria ou lá na Líbia ardente" e a Carlos Drummond de Andrade, "Europa, França e Bahia" (título um pouco modificado de um de seus poemas). Sobre essa última hipótese, Emanuel de Moraes prefere associá-la à conhecida expressão do cancioneiro popular, “Oropa, França, Bahia” (MORAES, 1971, p. 153).

Sem refutar inteiramente essa associação, pode-se argumentar que o verso de Bandeira em seu contexto dialoga rigorosamente com o título drummondiano e o tema nele desenvolvido, ainda que com diferença de tonalidade e espírito. O de Bandeira é nostálgico e o de Drummond, repleto de ironia. Une-os o tema do exílio. Na referência popular, a expressão tem o primeiro termo estropiado. Essa possibilidade analítica diversa pode ser devedora do carácter de double coding, de que se reveste a obra literária, conforme a "leitura do intervalo" dos diferentes leitores.

\author{
- Muito contas, cotovia! \\ E que outras terras distantes \\ Visitaste? Dize ao triste. \\ - Líbia ardente, Cítia fria, \\ Europa, França, Bahia... \\ (BANDEIRA, 1966a, p. 210).
}

$\mathrm{Na}$ passagem camoniana, Inês de Castro pede que a exilem numa região quente ("Líbia ardente”) ou fria (“Cítia fria”), se quisessem castigá-la, apesar de inocente.

O poema de Carlos Drummond de Andrade fala do brasileiro entediado de terras europeias, terminando por uma referência explícita e irônica à "Canção do exílio", de Gonçalves Dias:

\author{
Chega! \\ Meus olhos brasileiros se fecham saudosos. \\ Minha boca procura a "Canção do exílio". \\ Como era mesmo a "Canção do exílio"? \\ Eu tão esquecido de minha terra... \\ Ai terra que tem palmeiras \\ Onde canta o sabiá! \\ (ANDRADE, 1979, p. 74).
}

A sintonia emocional com os dois poetas instigou Bandeira a perguntar por sua terra natal, Pernambuco, e, ao receber do pássaro resposta afirmativa: “- Voei ao Recife, no Cais / Pousei da Rua da Aurora" (BANDEIRA, 1966a, p. 210) - desencadeou-se em sua memória a SOLETRAS - Revista do Departamento de Letras da FFP/UERJ 
lembrança da época infantil, suscitando a reprodução dos versos de Casimiro de Abreu. Observe-se que os versos transcritos imitam a sintaxe camoniana, em outra alusão, desta vez indireta, ao bardo português.

Tematizando um duplo exílio, o espacial (a terra natal, Pernambuco) e o temporal (a infância), encontrou companhia exemplar nos poetas que igualmente trataram de exílio espacial (Camões e Carlos Drummond de Andrade), cada um com sua especificidade, além da alusão oblíqua a Gonçalves Dias e a temporal (Casimiro de Abreu).

Quem não encontraria, no primeiro verso de "Bacanal" (Carnaval) - "Quero beber! cantar asneiras" - reminiscências em tom paródico do verso inicial do antológico "Mocidade e morte" (“Oh! Eu quero viver, beber perfumes”), de Castro Alves e, em ambos o mesmo grito desesperado de desejo de evasão, de vontade de viver?

Ainda de "Mocidade e morte", embora de associação mais delicada, porque mais sutil, apropria-se de um dístico castroalvino que o poeta pernambucano considerava uma joia da poesia brasileira, dois versos que, no seu entendimento, são dotados "de raro sortilégio verbal" (BANDEIRA, 1954, p. 6): "Vem! formosa mulher - camélia pálida, / Que banharam de pranto as alvoradas" (ALVES, 1960, p. 88).

Esses versos contêm uma das imagens prediletas de Bandeira, a qual consiste na aproximação metafórica entre a pureza do alvorecer e o significado purificador das lágrimas. Em “Toante" (Carnaval), a disposição sintática das palavras cria uma realidade poética distinta da dos versos de Castro Alves, mas a identidade semântica das imagens foi preservada. No poema de Manuel Bandeira, a imagem foi condensada em um único verso: "Molha em teu pranto de aurora as minhas mãos pálidas" (BANDEIRA, 1966a, p. 73).

Exemplos colhidos em outros poemas demonstram que a imagem é recorrente constitui um de seus versos obsessivos -, com variantes expressionais. No primeiro "Belo belo" (Lira dos cinquent'anos), “A aurora apaga-se / E eu quero as mais puras lágrimas da aurora"; em "Escusa" (Belo belo), "Há anos que não vejo romper o sol, que não lavo os olhos nas cores das madrugadas"; também em "Lua nova" (Opus 10): "Volto a tomar conhecimento da aurora. / Volto a banhar meus olhos no mênstruo incruento das madrugadas".

Gonçalves Dias, outro romântico dileto de Manuel Bandeira, além das inúmeras lições sobre técnica versificatória, deu-lhe também os antológicos versos de "I-Juca Pirama" - "Sou bravo, sou forte, / Sou filho do Norte" - parodiou-os na sua "Canção para a minha morte" (Estrela da tarde): "Bem que filho do Norte / Não sou bravo nem forte" (BANDEIRA, 1966a, p. 292). 
Em "O fauno" (Estrela da tarde), o verso "Ninfa! Aonde estás? Aonde?...”, mais os seguintes da última estrofe, "Grita o fauno, mas só o eco / De sua voz lhe responde" (BANDEIRA, 1966, p. 254), recordam a angústia de Cláudio Manuel da Costa, clamando por sua Nise, sem obter resposta, sequer do eco, ao contrário do que ocorreu no poema bandeiriano. Confronte-se a passagem com o trecho correspondente do famoso soneto XIII, de Cláudio Manuel da Costa: "Nem ao menos o eco me responde! / Ah! Como é certa a minha desventura! / Nise? Nise? Onde estás? Aonde? Aonde?” (COSTA, 1903, v. 1, p. 109).

No poema de Manuel Bandeira, o tipo feminino retratado, uma ninfa, característico da poesia árcade, aproximou ainda mais os dois poetas.

Um fragmento de Rimbaud entrou sorrateiro num verso de "Infância" (Belo belo): "O cambrone - núcleo de poesia (“la fraicheur des latrines!”)” (BANDEIRA, 1966a, p. 206), mas não gratuitamente. E foi o próprio Bandeira quem justificou a presença do "vagabundo genial", falando de si como se falasse de outro:

Os cambrones do Recife eram o que havia de mais primitivo, mas por que o menino de sete anos, futuro poeta a seu malgrado, gostava de estar ali? Só muitos anos depois, homem feito, descobriu a razão, ao ler o poema de um menino genial, que se chamava Jean-Nicolas-Arthur Rimbaud, poema intitulado "Les poètes de sept ans", escrito aos dezesseis anos. Dizia ele, a meio do poema:

\section{L'été}

Surtout, vaincu, stupide, il était entêté

À se renfermer dans la fraicheur des latrines.

Havia, muito, essa "fraicheur" no cambrone daquele quintal da Rua da União...

(BANDEIRA, 1966b, p. 5-6).

Neste depoimento, mais que a identificação do fragmento em francês, interessa destacar a importância que teve, na formação intelectual de Bandeira, a leitura de textos literários, notadamente os de poesia, suspeita que se confirma com a confissão do próprio poeta, entre inúmeros outros exemplos, sobre a gênese da admirável "Balada das três mulheres do sabonete Araxá" (Estrela da manhã): "O trabalho de composição está em eu ter adequado às circunstâncias de minha vida fragmentos de poetas queridos e decorados em minha adolescência - Bilac, Castro Alves, Luís Delfino, Eugênio de Castro, Oscar Wilde” (BANDEIRA, 1954, p. 96-97).

Ficou eufórico quando recebeu de Alphonsus de Guimaraens Filho convite para redigir o prefácio dos Sonetos da ausência do amigo. E correspondeu ao pedido: 
Aqui está o prefácio prometido para os Sonetos da Ausência. É também um Soneto, - porque afinal me pareceu que não ficava bem nenhuma explicação preliminar a livro que se explica tão bem por si mesmo na sua emoção tão fina e nos seus ritmos tão raros (BANDEIRA, 1974, p. 91).

E inicia o soneto-prefácio com uma citação de Wordsworth, um dos grandes poetas do Romantismo inglês: "Scorn not the sonnet, disse o inglês. Ouviste / O conselho do poeta [...]" (BANDEIRA, 1996a, p. 179), e incluiu-o, depois, na Lira dos cinquent'anos, com o título de "A Alphonsus de Guimaraens Filho".

Às vezes, ocorre o aproveitamento de um texto inteiro, como ocorre em "Teresa" (Libertinagem). Segundo Manuel Bandeira, foi construído como "tradução para moderno" do “Adeus de Teresa", de Castro Alves, com o propósito de "trasladar com a máxima fidelidade, sem permitir que na versão se insinuasse qualquer parcela do meu sentimento pessoal, o que espero ter conseguido" (BANDEIRA, 1994, p. 51). Claramente se constata, através do confronto dos poemas, que se apropriou do "Adeus" de Castro Alves para elaborar uma saborosa paródia. Aproveitando a técnica cubista, desmontou a figura feminina e arrematou o poema com outra apropriação, desta vez subvertendo a palavra bíblica, sem mencioná-la no comentário:

A primeira vez que vi Teresa

Achei que ela tinha pernas estúpidas

Achei também que a cara parecia uma perna

Quando vi Teresa de novo

Achei que os olhos eram muito mais velhos que o resto do corpo

(Os olhos nasceram e ficaram dez anos esperando que o resto corpo

[nascesse

Da terceira vez não vi mais nada

Os céus se misturaram com a terra

E o espírito de Deus voltou a se mover sobre a face das águas

(BANDEIRA, 1966a, p. 11).

Os fragmentos do livro do "Gênesis" (Bíblia Sagrada), aproveitados nos versos que encerram o poema (penúltimo e último) correspondem, pela ordem capítulo 1, versículos 6 a 10 (separação do céu e da terra) e versículo 2 ("e o Espírito de Deus movia-Se sobre a superfície das águas”). À maneira divina, cria a imagem de Teresa pela palavra poética, mas pela inversão: Deus cria o mundo, a partir do caos, separando o céu e a terra, o dia e a noite, pondo ordem nos elementos; o poeta, onde havia ordem, instaura a desordem e o caos. 
Além dessa Teresa inspirada em Castro Alves, aparecem outras com o mesmo nome, quase sempre em perspectiva intertextual, como aquela elogiada no "Madrigal tão engraçadinho" (Libertinagem) que se reporta ao "Porquinho-da-índia" (Libertinagem). Aqui, dialoga com a própria obra, fato não raro em sua poética. "Lua nova" (Opus 10) reproduz, com variante, um verso de "Comentário musical" (Libertinagem); "Antologia" (Estrela da tarde) se organiza pela "colagem" de versos de onze poemas diferentes, de Libertinagem até Opus 10.

Entre os poemas que se organizaram sob a égide do diálogo intertextual, há o caso curioso do "Poema encontrado por Thiago de Mello no Itinerário de Pasárgada" (Opus 10), o qual, a partir do título, fornece a pista de sua elaboração, embora atribua o achado a outro poeta (Thiago de Mello). Permite avaliar o processo bandeiriano de atribuir força expressional à palavra, mantendo-se fiel à lição de Mallarmé ("poesia se faz com palavras e não com idéias e sentimentos"), mediante determinados ajustes:

\author{
Vênus luzia sobre nós tão grande, \\ Tão intensa, tão bela, que chegava \\ A parecer escandalosa, e dava \\ Vontade de morrer \\ (BANDEIRA, 1966, p. 212).
}

Agora, para comparação, o fragmento em prosa:

Em 1926 passei duas semanas num sítio distante de Mangaratiba umas duas horas de canoa. A ida para lá, noite fechada ainda, foi a viagem mais bonita que fiz na minha vida. Vênus luzia sobre nós tão grande, tão intensa, tão bela, que chegava a parecer escandalosa e dava vontade de morrer (daquela hora é que iria sair o título de meu livro seguinte: Estrela da Manhã) (BANDEIRA, 1954, p. 94). (Grifo meu).

Autêntico poema "desentranhado" de um único fragmento, estabelecendo um tenso diálogo intertextual - poesia e prosa, emoção lírica e relato autobiográfico, linguagem referencial e linguagem poética, invenção poética e depoimento -, o poema é um veemente exercício de manipulação da linguagem literária, em alto nível.

De dado verídico, em que o relato prosaico é de pura transparência comunicativa, bastou ao poeta, mediante hábeis manejos de organização estrutural, inclusive cortes sintáticos na sequência frasal, para torná-lo prenhe de ambiguidade e carga poética, isolando- 
o do contexto maior e dispondo os sintagmas selecionados em linhas descontínuas perfeitamente regulares, em termos de métrica e marcação rítmica.

São três decassílabos e um hexassílabo de pé quebrado, ritmados regularmente (combinação harmoniosa entre verso sáfico e verso heroico), dentro da tradição versificatória em língua portuguesa. O estado pleno de poesia é alcançado, não por essa circunstância meramente exterior, mas pelo uso expressivo de determinadas palavras, estrategicamente distribuídas no corpo do texto. O impacto maior fica por conta daquela "Vênus" com que se inicia o poema, carregada de mistério, decorrente da ambiguidade semântica (tanto pode significar o planeta Vênus - no texto em prosa, a referência é clara e unívoca -, como a deusa mitológica do amor ou assumir a postura simbólica do erotismo feminino). Acrescente-se a isso, para intensificar essa plurissignificação, os atributos a ela dirigidos (grande, intensa, bela), modificados pelo advérbio "tão", em repetição ternária, nunca igual a si mesmo, marcando o ritmo de uma sinuosidade sugestiva, cambaleante, que torna "Vênus" ainda mais enigmática, precipitando a força emocional, no enjambement do segundo verso. As rimas, internas e externas, ajudam a compor o efeito encantatório, além de contribuírem decisivamente para a construção da fluidez rítmica, alma do poema. Como arremate, destaque-se o uso dos verbos no imperfeito do indicativo, sugerindo o prolongamento da indefinição temporal da cena poética, suspensa no passado para assegurar a magia do presente.

É no poema "Antologia" (Estrela da tarde) que o centão, entendido em sua formulação mais ortodoxa, atinge a perfeição temática e estrutural.

O poema constrói-se a partir da seleção de versos que seria, segundo o próprio Manuel Bandeira, uma espécie de súmula, um resumo de toda a sua obra poética para o leitor não familiarizado com sua longa trajetória. Considerada a declaração em termos absolutos, constata-se que se trata de um objetivo de difícil ou impossível realização. No entanto, se se considerar certos aspectos contextuais e estruturais dessa composição, o propósito não soa tão utópico, pelo menos em parte. Leia-se atentamente o poema:

\section{"Antologia"}

A vida

Não vale a pena e a dor de ser vivida.

Os corpos se entendem mas as almas não.

A única coisa a fazer é tocar um tango argentino.

Vou-me embora p'ra Pasárgada! 


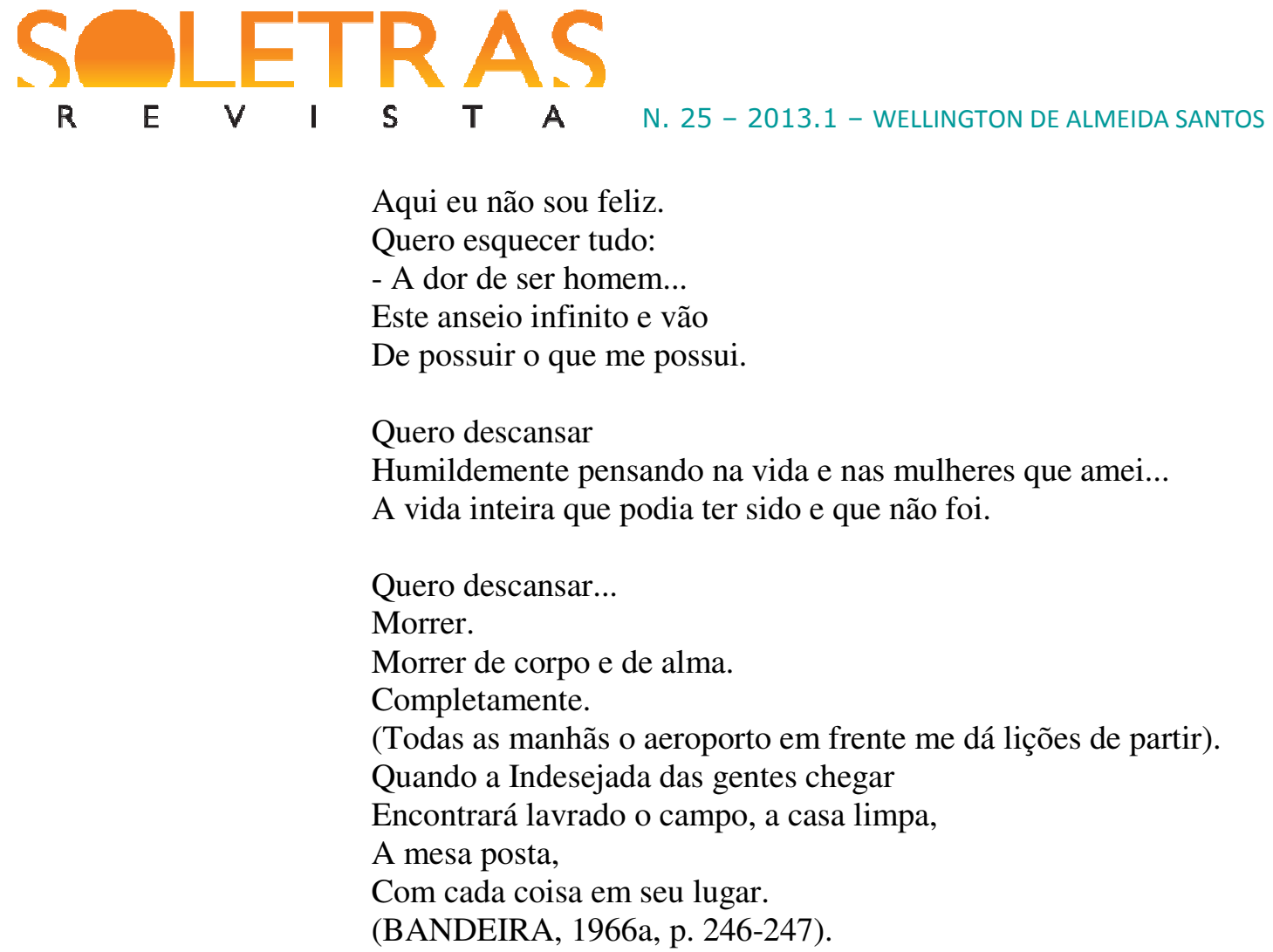

Aqui eu não sou feliz.

Quero esquecer tudo:

- A dor de ser homem...

Este anseio infinito e vão

Humildemente pensando na vida e nas mulheres que amei...

Quero descansar...

Morrer.

Morrer de corpo e de alma.

Completamente.

(Todas as manhãs o aeroporto em frente me dá lições de partir)

Quando a Indesejada das gentes chegar

Encontrará lavrado o campo, a casa limpa,

Com cada coisa em seu lugar.

(BANDEIRA, 1966a, p. 246-247).

Primeiramente, considere-se que os versos que integram "Antologia" foram retirados da obra madura de Bandeira (de Libertinagem, 1930, a Opus 10, 1952). Exclui-se, portanto, o último livro (Estrela da tarde, 1963), onde o poema se encontra, mas somente na edição das poesias completas (Estrela da vida inteira,1966), comemorativa dos 80 anos de nascimento de Manuel Bandeira, verdadeiro testamento literário. Registre-se que houve edições anteriores de Estrela da tarde (em 1958, integrando a edição de Poesia e prosa, da editora Aguilar, em dois volumes, e a mencionada, de 1963, aumentada). Portanto, "Antologia" só aparece na terceira edição de Estrela da tarde.

São cinco as obras que cedem versos, com onze poemas no total:

a) V. 1 e 2 - "Soneto inglês n' 2" (Lira dos cinquent'anos);

b) V. 3 - "Arte de amar" (Belo belo);

c) V. 4 "Pneumotórax" (Libertinagem);

d) V. 5 e 6 - "Vou-me embora pra Pasárgada" (Libertinagem);

e) V. 7 - "Cantiga" (Estrela da manhã);

f) V. 8 - "Presepe" (Belo belo);

g) V.9 e 10 - "Resposta a Vinícius" (Belo belo);

h) V. 11 - "Cantiga" (Estrela da manhã);

i) V 12. "Poema só para Jaime Ovalle" (Belo belo);

j) V 13. "Pneumotórax" (Libertinagem); SOLETRAS - Revista do Departamento de Letras da FFP/UERJ Número 25 (jan.-jun. 2013) ISSN: 2316-8838 
k) V 14 - "Cantiga" (Estrela da manhã);

1) V. 15 a 17 - "A morte absoluta" (Lira dos cinquent'anos);

m) V. 18 - "Lua nova" (Opus 10);

n) V. 19 a 22 - "Consoada" (Opus 10).

O título (antologia) sugere um trabalho de reorganização de espaços poéticos anteriores e, portanto, uma atitude crítica que mescla revisão e atualização. Lido isoladamente, o poema mostra-se como obra lacunosa a que faltam informações para adquirir coerência e sentido, exceto na última estrofe onde os versos, finalmente, sintetizam o grande tema da obra bandeiriana, a morte, em sequência harmoniosa. Convicção plena de que o fim já não é assustador, tampouco revestido de sentimento trágico, mas algo desejável, com a sensação do dever cumprido. O leitor é obrigado a usar um método de leitura que combine, como pressuposto compulsório, a recuperação dos textos que cederam versos para a composição e o modo pelo qual esses versos se relacionam no novo espaço poético. Dessa maneira, percebe-se que o fragmento, lido em dois espaços poéticos distintos, adquire, também, status semântico e simbólico diferentes, de acordo com o contexto poético. Entendase, sob esse ângulo, que o mesmo verso é "outro". "Antologia” desenvolve uma história poética cuja compreensão não é inteiramente possível, sem recorrer às partes que o compõem. "Antologia" revê a história parcial de um poeta (excluem-se os três primeiros livros - A cinza das horas, 1917; Carnaval, 1919; e O ritmo dissoluto, este último inclui-se nas Poesias (1924, e o último), Estrela da tarde, pois faz parte dele, mas apenas na terceira edição, em 1966, com o título de Estrela da vida inteira), contada pelo próprio poeta que, sendo o mesmo, já é outro, modificado pelo tempo e pelas circunstâncias. O tempo de cada poema é distinto um do outro, mas o momento da compilação é único.

Outro fator importante para a interpretação de "Antologia" é que a maioria dos poemas de onde são retirados os "farrapos de textos" que o compõe tematiza a morte, enquanto dado individual. É a morte de Manuel Bandeira que Manuel Bandeira canta, mas já na fase de enfrentamento ostensivo ou da superação irônica, até a aceitação e o desejo de morrer.

Em "Pneumotórax", ao anúncio de morte iminente, o poeta supera o impasse pelo humor negro dos últimos versos: “- Então, doutor, não é possível tentar o pneumotórax? / Não. A única coisa a fazer é tocar um tango argentino". 
Em "Vou-me embora pra Pasárgada", embora a morte só surja por exclusão, a fuga se dá pela construção utópica, pela subversão total de tempo e espaço, permitindo ao poeta não só voltar à infância feliz, como simultaneamente realizar desejos de adulto, impossíveis no plano "real", além de, independente de idade cronológica, desempenhar atividades interditadas pela doença ("Montarei em burro brabo / Subirei no pau-de-sebo / Tomarei banhos de mar").

"Lua nova" e "A morte absoluta" evoluem para uma espécie de "pedagogia" da morte. O poeta prepara-se para morrer. O processo de aprendizagem da morte atinge o máximo de depuração em "Consoada", canto resignado diante do irremediável, ainda que, nem uma só vez, a palavra morte apareça no texto uma única vez (ela é a "Indesejada das gentes", a “iniludível”).

Entretanto, essa visão altamente subjetiva da morte começa a ser questionada, em termos relativos, quando o poeta introduz, em "Antologia", versos de poemas que não abordam a morte, e sim temas mais universais, menos pessoais. O verso 3, "Os corpos se entendem mas as almas não", pertence, na origem, ao poema "Arte de amar", o qual trata de relações amorosas, no plano físico. Vindo antes de "A única coisa a fazer é tocar um tango argentino", modifica o sentido original deste verso. Em "Pneumotórax", o verso "A única coisa a fazer é tocar um tango argentino" aparece como solução irônica para o drama pessoal do poeta (entregar-se à adesão conformada da morte iminente). Já em “Antologia”, este mesmo verso evidencia-se como resposta, com o mesmo teor irônico, ao impasse constituído pela impossibilidade de comunicação amorosa entre os seres humanos (no plano metafórico, por contaminação simbólica, poder-se-ia admitir que indicia a "morte" do entendimento entre as pessoas).

A continuação da análise mostrará tensões semelhantes. Acentua-se a ideia de que o trabalho de colagem resultou no abandono gradativo do sentido primitivo dos versos "antológicos" para uma crescente afirmação de novos conteúdos, a despeito da preservação de sua estrutura sintática individual. As novas relações frasais desencadearam novos sentidos, tornando "Antologia" um poema que assume a postura de emblema da solidariedade humana, no tratamento temático da morte. Antes, a morte era vista como algo pessoal, passando do desespero à resignação, mas sempre do ponto de vista do interesse do "eu-lírico". Em "Antologia", a morte é um acontecimento inerente à condição humana em geral, e não um fenômeno que afeta um só indivíduo. O que se quer esquecer, finalmente, não é a doença que 
leva o "eu-lírico" à morte, conforme atesta o poema original, mas é a dor maior e universal: "A dor de ser homem".

Sem esquecer que a morte existe para si, a atitude de conformação diante do inevitável, exposta em "Consoada", amplia-se em comunhão universal.

É provável que Manuel Bandeira não tenha se dado conta de que o leitor incipiente de sua obra, a quem se destina "Antologia", por suposição, intrigado com o título do poema, fosse buscar mais informações a respeito dele e, ainda por suposição, estimulado pela investigação, chegasse à descoberta da "ironia intertextual”: o pretenso resumo, na verdade, é um parcial remanejamento temático, porquanto estabelece novas relações entre determinados núcleos temáticos, sobretudo o amor e a morte.

\section{Referências bibliográficas:}

ALVES, Castro. Mocidade e morte. In: Obra completa. Rio de Janeiro: Aguilar, 1960.

ANDRADE, Carlos Drummond de. Europa, França e Bahia. In: Poesia e prosa. Rio de Janeiro: Aguilar, 1979.

BANDEIRA, Manuel. Itinerário de Pasárgada. Rio de Janeiro: Edições Jornal de Letras, 1954.

Poesia e prosa. Rio de Janeiro: Aguilar, 1958, v. 2.

Estrela da vida inteira. Rio de Janeiro: José Olympio, 1966a.

Andorinha andorinha. Rio de Janeiro: José Olympio, $1966 \mathrm{~b}$.

. Itinerários: cartas a Alphonsus de Guimaraens Filho. In: . et al. São Paulo: Duas Cidades, 1974.

Duas traduções para moderno acompanhadas de comentário. In: SENNA, Homero (Org.). O mês modernista. Rio de Janeiro: Fundação Casa de Rui Barbosa, 1994.

BARBOSA, João Alexandre. Leituras: o intervalo da literatura. In: A leitura do intervalo. São Paulo: Iluminuras; Secretaria de Estado de Cultura de São Paulo, 1990.

BARTHES, Roland, apud VIGNER, Gerard. Intertextualidade, norma e legibilidade. In: et al. O texto: escrita e leitura. Campinas, SP: Pontes, 1988.

CORREIA, Raimundo. Plenilúnio. In: 1960. Poesia completa e prosa. Rio de Janeiro: Aguilar,

COSTA, Cláudio Manuel da. Soneto XIII. Obras poéticas. Rio de Janeiro: Garnier, 1903, v. 1. 
DRUMMOND, Carlos Drummond de. Europa, França e Bahia. In: . Poesia e prosa. Rio de Janeiro: Aguilar, 1979.

ECO, Umberto. Ironia intertextual e níveis de leitura. In: Sobre a literatura. 2. ed. Rio de Janeiro: Record, 2003.

ELIOT, T.S. A tradição e o talento individual. In: Ensaios de doutrina crítica. Lisboa: Guimarães Editores, 1962.

FONDA, Enio. O centão poético na literatura latina. Revista de Letras, Assis, SP, 5, p. 125$148,1964$.

HORTA, Anderson Braga. Aspectos da linguagem poética de Manuel Bandeira. In: et al. Semana de estudos sobre Manuel Bandeira. Brasília, DF: CEUB, 1982.

HUIZINGA, Johan. A imagem da morte. In: O outono da Idade Média. São Paulo: Cosac Naify, 2010.

MIRANDA, Sá de. Soneto 122. In: Obras completas. Lisboa: Livraria Sá da Costa, 1937, v. 1.

MOISÉS, Massaud. Elegia. In: Dicionário de termos literários. São Paulo: Cultrix, 1974.

MORAES, Emanuel de (Org.). In: BANDEIRA, Manuel. Seleta em prosa e verso. Rio de Janeiro: José Olympio; INL, 1971.

PAZ, Octavio. A inspiração. In: _. O arco e a lira. Rio de Janeiro: Nova Fronteira, 1982.

PERRONE-MOISÉS, Leyla. A intertextualidade crítica. In: __ et al. Intertextualidades. Coimbra: Almedina, 1979.

READ, Herbert. O poeta e sua musa. In: . As origens da forma na arte moderna. Rio de Janeiro: Zahar, 1967.

SCHLEGEL, Friedrich. O dialeto dos fragmentos. São Paulo: Iluminuras, 1997.

SHELLEY. Defesa da poesia. Lisboa: Guimarães Editores, 1972.

TELES, Gilberto Mendonça. A bandeira de Bandeira. In: BRAYNER, Sonia (Org.). Manuel Bandeira. Rio de Janeiro: Civilização Brasileira; Brasília, DF: INL, 1980.

VIGNER, Gerard. Intertextualidade, norma e legibilidade. In: . et al. O texto: escrita e leitura. Campinas, SP: Pontes, 1988. 


\title{
Manuel Bandeira and the dialogue with the poetic tradition
}

\begin{abstract}
The theming of death opens and closes Manuel Bandeira's long poetic trajetory. The aim of this paper is to demonstrate that the poet overcame the impasse of the tragic feeling of death by means of a dialogue with other poets as well as with his own work, among other possible and pertinent formulations, through a singular poetic dialetics. In order to show how viable and relevant this critical path is, it was used a theoretical apparatus based upon intertextual technique and similar critical procedures.
\end{abstract}

Key words: Manuel Bandeira. Intertextuality. Poetry.

Recebido em: 07 de junho de 2013.

Aprovado em: 10 de julho de 2013. 